\title{
非弁膜症性心房細動例を対象としたワルファリンによる 脳梗塞発症一次予防一INRの差異による検討一
}

\author{
中島 一夫 林 由紀子
}

要旨：非弁膜症性心房細動 194 例（発症年歯 $65.1 \pm 10.5$ 歳, ワルファリン開始年齢 $69.5 \pm 8.8$ 歳, 男性 124 例, 女性 70 例, 慢性心房細動 157 例)を対象としてワルファリンによる脳梗塞発 症一次予防の後乃向き検討を行った。総観察期間 7,175 力月間で脳梗塞は 11 例 (年間発症率 1.8 \%)に，また脳出血は 3 例（年間発症率 $0.5 \%$ ）に生じた．平均 INR 別に低用量ワルファリン群

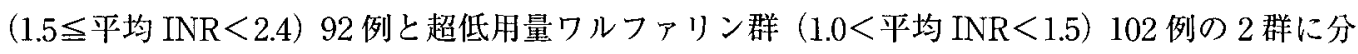
けて検討すると，臨床背景については有意差を認めなかった．脳梗塞発症率は低用量ワルファ リン群で年間 $0.6 \%$ と超低用量ワルファリン群の年間 $3.1 \%$ に比して有意に低率であったが（p $=0.028)$, 脳出血発症率は両群間で有意差がなかった $(0.3 v s 0.7 \% /$ 年, $\mathrm{p}=0.522)$. 本邦の非弁 膜症性心房細動例の脳梗塞発症一次予防には低用量ワルファリンが推奨される.

Key words : atrial fibrillation, warfarin, ischemic stroke, brain hemorrhage, primary prevention

（脳卒中 $23: 188-194,2001 ）$

\section{はじめに}

1980 年後半から 1990 年前半にかけて欧米では非弁 膜症性心房細動（以下, NVAF と略す）を対象とした 全身塞栓症抢よび脳梗塞発症一次予防の大規模研究の 成績が相次いで報告された ${ }^{1) 57}$.いずれの研究もワル ファリンの有用性が示され，目標 INR は 2.0 3.0が望 ましいとされた。一方，本邦では一次子防としてワル ファリンの有用性を示した研究はわずかに散見される 程度でけー10)，INRをどの程度に設定するかを検討した 前向き無作為研究は未だ存在していないため, 本邦の 脳梗塞二次予防の目標 INR 1.5 2.11) を一次予防の目 標 INRに用いているのが現状である. 今回, NVAF 例を対象としてワルファリンによる絲梗塞一次予防の 有用性及び至適用量を決定するための後ろ向き研究を 行った.

\section{対象および方法}

佐久市立国保浅間総合病院内科

(2000年 11 月 15 日受付, 2001 年 2 月 27 日受理)
対象は 1988 年 1 月から 2000 年 12 月迄に当施設で 登録されたNVAF 中, 症候性の脳梗塞または全身塞栓 症の既往を有さず，4カ月以上にわたりワルファリン を服用していた 194 例である。

NVAF 194 例の上記期間における脳梗塞および脳 出血発症率を算出するとともに, 原則として毎月 1 回 以上測定されたINRの平均值を症例ごとに計算し, 平 均 INR $\geqq 1.5$ の低用量ワルファリン群 (以下, 低用量 Wa 群と略す) と平均 $\mathrm{INR}<1.5$ の超低用量ワルファリ ン群（以下，超低用量 Wa 群と略す）の 2 群に分けて 同様な発症率の比較を行った。

脳梗塞は突発した局所神経症状が 24 時間以上持続 し, 頭部 CT (MRI) 上で梗塞像が証明されたもの, 脳 出血は突発した局所神経症状に加之画像上出血像が証 明されたものと定義した. 尚, 脳梗塞の発症機序によ る分類は行わなかった。

統計処理には, Macintosh Stat View Version 4.5 J を用いた。臨床背景の比較に関して, 連続変数に対し ては $\mathrm{t}$ 検定を, 非連続変数に対してはカイ 2 乗検定を 用いた。発症率の比較に関しては, Kaplan-Meier 法で 求めた累積曲線から logrank 法により検定した。各解 
析の有意水準は $\mathrm{p}<0.05$ とした.

\section{成 績}

1) 臨床背景

表 1 にNVAF 194 例の背景を示す. 心房細動(以下， $\mathrm{AF}$ と略す)発症平均年歯令は $65.1 \pm 10.5$ 歳, ワルファリ ン開始年齢は $69.5 \pm 8.8$ 藏, 男性が 124 例, 女性が 70 例, 発作例 $\mathrm{AF}$ が 31 例, 発作性から慢性に移行した $\mathrm{AF}$ が 6 例, 慢性 $\mathrm{AF}$ が 157 例であった. 基礎心疾患を みると, 高血圧, 虚血性心疾患, 僧帽弁逸脱症侯群, 心筋症および先天性心疾患の合併率はそれぞれ $55 \%$ ， $8 \%, 6 \%, 4 \%$ および $3 \%$ であり, 基礎心疾患を有さな い症例は $31 \%$ を占めた。また，甲状腺機能元進症は 5 $\%$ ，糖尿病は $26 \%$, 高脂血症は $9 \%$ に合併し，心不全 入院歴は $22 \%$ にみられた. 抗血小板薬との併用は 21 例 $(11 \%)$ にみられ，その内訳はアスピリン投与例が 20 例（1 日 81 100 mg)，チクロピジン投与例が，(1 日 $200 \mathrm{mg}$ ) であった。

平均 INR 1.5 を境界に全 194 例を分けると表 2 の上 うに低用量 $W a$ 群 $(1.5 \leqq$ 平均 INR $<2.4)$ が 92 例, 超低 用量 Wa 群 $(1.0<$ 平均 INR $<1.5)$ が 102 例となった。 低用量 Wa 群と超低用量 Wa 群の唕床背景を比較する と, 表 1 に示すように $\mathrm{AF}$ 発症年噛, ワルファリン開 始年齢, 男女比, 慢性 $\mathrm{AF}$ の頻度, 基礎心疾患の内容,
甲状腺機能六進症合併, 糖尿病合併, 高脂血症合併, 心不全入院歴および抗血小板薬併用のすべての項目に おいて 2 群間で有意差を認めなかった。

2）脳梗塞発症率（図 1)

総観察期間 7,175 力月 (平均 37.0 力月) 間で脳梗塞が 11 例発症し, 年間発症率は $1.8 \%$ であった. 低用量 Wa 群では総観察期間 3,709 力月間で脳梗塞が 2 例 $(0.6 \%)$ 年), 超低用量 $\mathrm{Wa}$ 群では総観察期間 3,466 力月間で脳 梗塞が 9 例 $(3.1 \% /$ 年) 発症した。累積発症率をみると 低用量 Wa 群は超低用量 Wa 群に比して有意に低率で あった (3.4\% vs $14.1 \%, p=0.028)$.

脳梗塞発症時 INR は, 低用量 Wa 群 2 例でそれぞれ $1.09,1.50$, 超低用量 Wa 群 9 例でそれぞれ 1.11, 1.24, $1.30,1.34,1.34,1.61,1.62,1.76,1.90$ であった.

3）脳出血発症率（図 2)

上記期間に打いて脳出血が 3 例 $(0.5 \% /$ 年) に生じ た. 低用量 Wa 群では脳出血が 1 例 $(0.3 \%$ 年)，超低 用量 Wa 群では脳出血が 2 例 $(0.7 \%$ 年) 発症した。累 積発症率をみると低用量 Wa 群と超低用量 Wa 群間で 有意差はなかった (1.1\% vs $3.3 \%, p=0.522)$.

脳出血発症時 INR は, 低用量 Wa 群 1 例で 1.38 , 超 低用量 Wa 群 2 例でそれぞれ $2.40,2.93$ であった。

表 1 非弁膜症性心房細動（NVAF）194 例の臨床背景

\begin{tabular}{|c|c|c|c|}
\hline & 全 体 & 低用量 Wa 群 & 超低用量 Wa 群 \\
\hline 症例数 & 194 例 & 92 例 & 102 例 \\
\hline $\mathrm{AF}$ 発症年龁 & $65.1 \pm 10.5$ 藏 & $65.9 \pm 9.6$ 藏 & $64.3 \pm 11.1$ 歳 \\
\hline Wa 開始年齢 & $69.5 \pm 8.8$ 歳 & $70.5 \pm 8.1$ 祡 & $68.5 \pm 9.4$ 藏 \\
\hline 男：女 & $(124: 70)$ & $(57: 35)$ & $(67: 35)$ \\
\hline 慢性 AF & $81 \%(157)$ & $80 \%(74)$ & $81 \%(83)$ \\
\hline \multicolumn{4}{|l|}{ 基礎心疾患 } \\
\hline 高血压 & $55 \%(107)$ & $55 \%(51)$ & $55 \%(56)$ \\
\hline 虚血性 & $8 \%(15)$ & $7 \%(6)$ & $9 \%(9)$ \\
\hline MVP & $6 \%(11)$ & $8 \%(7)$ & $4 \%(4)$ \\
\hline 心㳙症 & $4 \%(8)$ & $4 \%(4)$ & $4 \%(4)$ \\
\hline 先天性 & $3 \%(6)$ & $3 \%(3)$ & $3 \%(3)$ \\
\hline な し & $31 \%(61)$ & $32 \%(29)$ & $31 \%(32)$ \\
\hline 甲状腺機能元進症 & $5 \%(9)$ & $2 \%(2)$ & $7 \%(7)$ \\
\hline 糖疗病 & $26 \%(50)$ & $24 \%(22)$ & $27 \%(28)$ \\
\hline 高脂血症 & $9 \%(18)$ & $13 \%(12)$ & $6 \%(6)$ \\
\hline 心不全入院歴 & $22 \%(42)$ & $21 \%(19)$ & $23 \%(23)$ \\
\hline 抗血小板薬併用 & $11 \%(21)$ & $11 \%(10)$ & $11 \%(11)$ \\
\hline
\end{tabular}


表 2 非弁膜症性心房細動 (NVAF) 194 例の平均 INR の分布

\begin{tabular}{c|c|c}
\hline & 平均 INR & 症例数 \\
\hline 低用量 Wa 群 & $2.0 \sim 2.4$ & 2 \\
$(92$ 例 $)$ & $1.9 \sim 2.0$ & 2 \\
& $1.8 \sim 1.9$ & 2 \\
& $1.7 \sim 1.8$ & 3 \\
& $1.6 \sim 1.7$ & 27 \\
\hline 超低用量 $\mathrm{Wa}$ 群 & $1.5 \sim 1.6$ & 56 \\
\hline (102 例) & $1.3 \sim 1.4$ & 37 \\
& $1.2 \sim 1.3$ & 31 \\
& $1.1 \sim 1.2$ & 22 \\
& $1.0 \sim 1.1$ & 4 \\
\hline
\end{tabular}

\section{考察}

脳塞栓症に代表される全身塞栓症を発症した NVAF 例に対して二次予防としてワルファリンを投 与することに異論をはさむ医師はいない，一方，全身 塞栓症の既往を有さないNVAF 例に対して一次予防 として抗凝固ないし抗血小板療法を行うべきか, 行う としたらいかなる症例に行うべきかという問題に刘し て欧米では十分な検討1) -5121 - -44 がなされているのに対 し，本邦では無作為前句き研究が存在しないため現時 点において一定の結論を導き出すのは難しい。

当施設では，欧米に㧍ける上述した研究や当施設独 自の後ろ向き研究 ${ }^{815)}$ の結果から, 慢性执よび繰り返す 発作性 NVAF 例に対しては積極的に抗凝固療法を 行ってきた。本報告は一施設の後ろ向き検討であり， 症例もワルファリン群のみの 194 例と決して多数例と は言えないが，以下の事実が導き出されたことは注目 に值する. (1)欧米に比しょり低用量のワルファリンで 同等の脳梗塞一次予防効果が得られる可能性が高い. (2)低用量ワルファリン群は超低用星ワルファリン群に 比して有意に脳梗塞発症率が低率であった。

(1)に関連して，AFを対寡とした抗血栓療法による 脳梗塞発症一次予防の欧米抢よび本邦の成績を表 3 お よび表 4 に示す. 欧米の報告は全て前向き無作為研究 であるのに刘して本邦ではCOOPAT studyを除いて すべてが後ろ向き研究である，対象が $\mathrm{AF}$ 全体から慢 性 NVAF と一定でない, エンドポイントが異なる，目 標 INR が異なるなどの差異があり単純に欧米と本邦 の成績を比較することに問題はあるが，ある程度の傾
向は導き出せると思われる。欧米の報告1)ー5”をまとめ ると, 脳梗塞発症率はプラセボ投与.群で 3.0 〜 $7.4 \%$ 年, ワルファリン㙩法群で 0.4 3.5\%/年とワルファリ ン療法による減少率は 37〜86\%であった。本邦での脳 梗塞発症率 ${ }^{6} \sim(0)$ は無治療群で $2.2 \sim 6.4 \% /$ 年, ワルファ リン療法群で 1.4〜2.5\%/年（ワルファリン療法による 減少率は 41〜 67\%）と欧米の成績とほとんど差がない ことがわかる。また，ワルファリン療法による脳出血 発症率は COOPAT study 除いて欧米，本邦の成績 ともすべて $1 \% /$ 年以内であった. 欧米と本邦の大きな 美簧㹥目標INRである。欧米での目標 INR は，BAATAFでの 1.5 2.7 と SPINAFでの 1.4〜2.8を除い たその他の報告ではすべて 2.0 以上であり，一次予防 のための目標 INR は2.0〜3.0が適当と結論づけてい る.一方, 本検討において INR 2.0〜3.0を満たした症例 は全体のたった $1 \%$ に過ぎず，残りの症例はすべて INR 2.0 未満の低用量群であった. 以上より本邦では欧 米より低用量のワルファリン療法にて同程度の一次予 防効果が得られる可能性が高いと考えられるが，その 他の本邦報告例での実際の INR の記載がないため本 結論に至るためにはさらなる報告の皘み重ねが必要で あろう。

(2)に関して，本邦ではYamaguchiらの二次予防の 成績(1からワルファリンによる脳梗塞一次予防の目標 INRも 1.5 2.1 が適当であるとのコメントが多い。そ こで本検討では INR 1.5 前後で低用量ワルファリン （1.5 平均 INR<2.4）群と超低用量ワルファリン（1.0 <平均 INR<1.5）群に分けて，各発症率を比較してみ た。 その結果, 脳梗塞発症率は低用量ワルファリン群 において有意に低率であった $(0.6 \%$ vs $3.1 \% /$ 年, $\mathrm{p}=$ 0.028)。一方, 脳出血発症率梳両群とも $1 \%$ /年以下で 2 群間で差がなかった。

本報告では抗血小板薬の效果について検討をしてい ないが，表 3 のようにAFASAK の報告”では1日75 $\mathrm{mg}$ のアスピリン投与群の脳梗塞発症はプラセボ群と 有意差なし, SPAF-I $\mathrm{I}^{3)}$ の成績では1日 $325 \mathrm{mg}$ のアスピ リン投与群はプラセボ群より有意に脳梗塞発症が低率

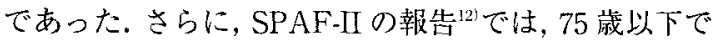
脳梗塞発症りスク（高血压の既往，全身塞栓症の既往 または最近の心不全歴）を有するNVAF 例ではワル ファリン療法が，脳梗塞発症リスクを有さない例では アスピリン療法が推奖され, 75 歳以上例ではワルファ リンとアスピリンの優少は結論がでないとした，本邦 では表 4 に示すように抗血小板薬の効果は無治療群と 


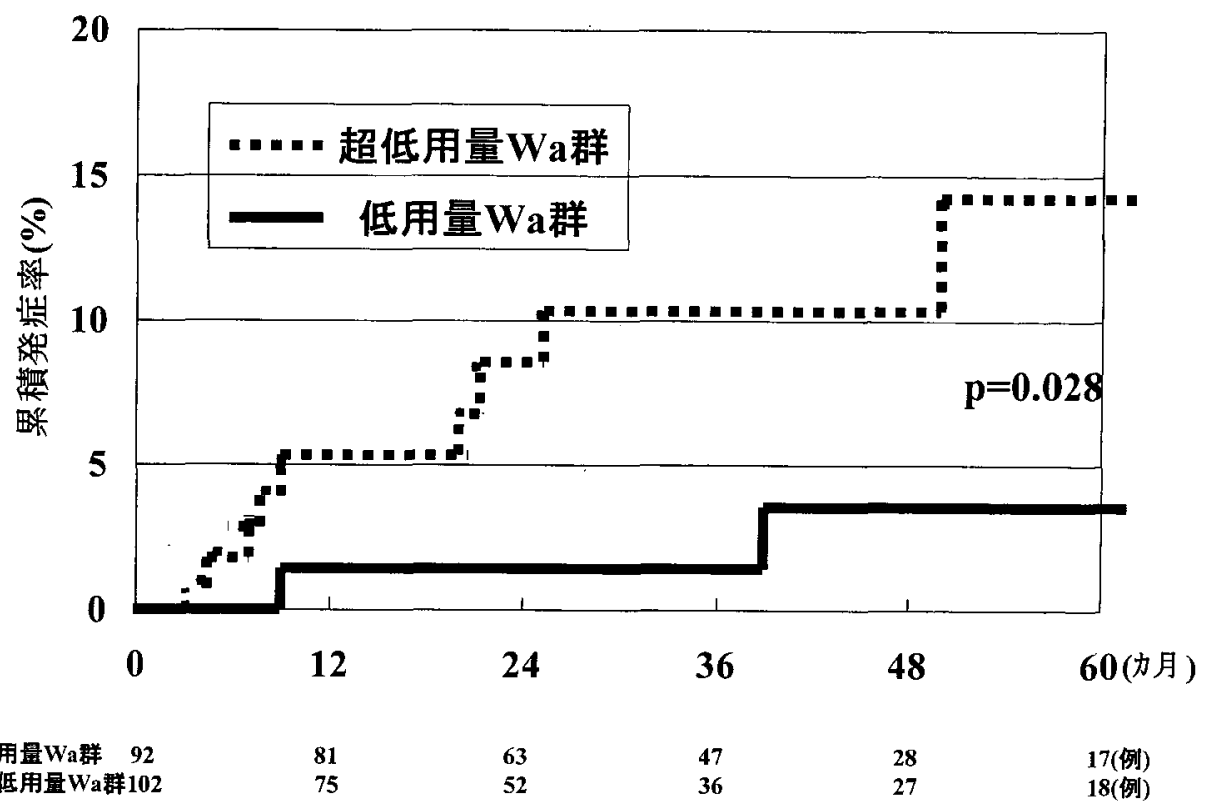

図 1 低用量ワルファリン群抢よび超低用量ワルファリン群の脳梗塞累皘発症率

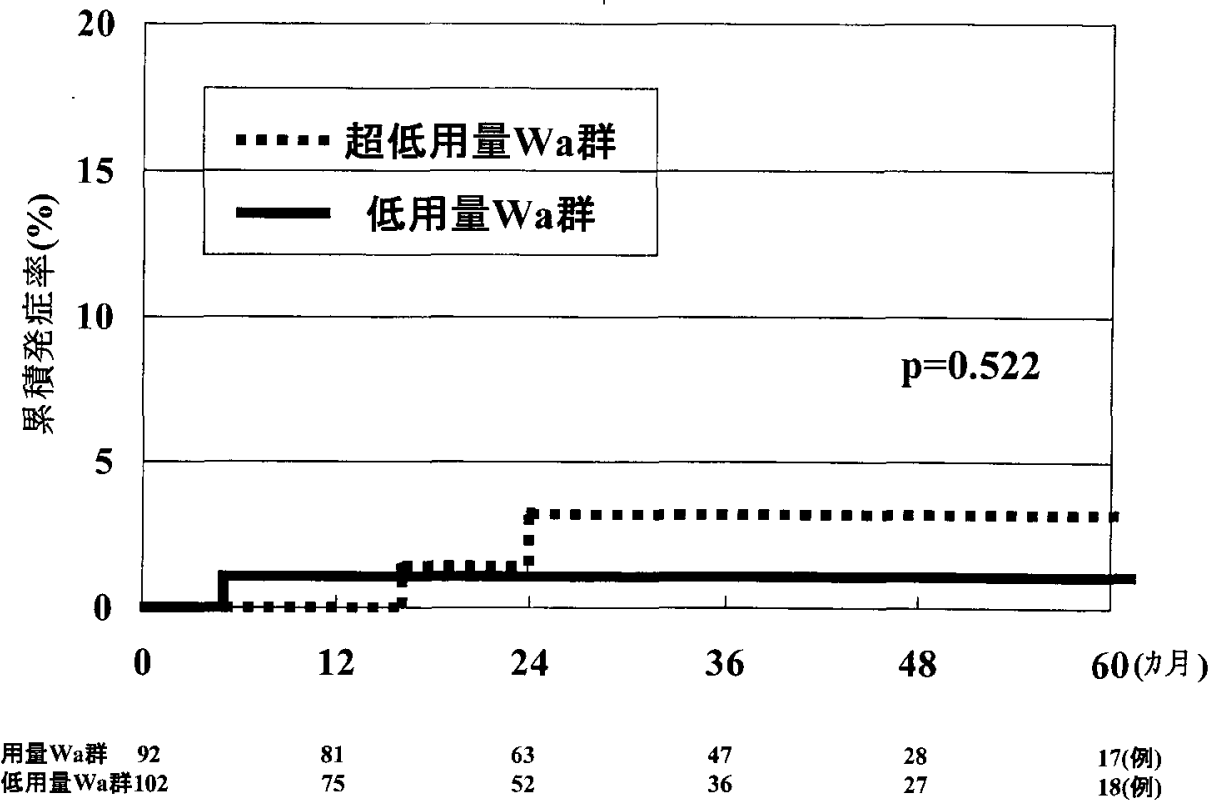

図 2 低用量ワルファリン群および超低用量ワルファリン群の脳出向䇣積発症率

差がなかったという報告が多いままた，固定・低用量 のワルファリンとアスピリン併用による脳梗塞予防効

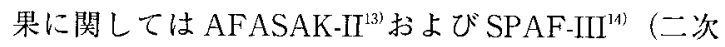

予防を含む）にて否定的な見解が報告された。

AFI/ACCP Consensus ${ }^{16)}$ は, 高血压の既往, 糖尿病, 脳梗塞または TIA の既往, 虚血性心疾患,うっ血性心 
表 3 心房細動例を対象とした脳梗塞発症一次予防の成䋶（欧米）

\begin{tabular}{|c|c|c|c|c|c|c|c|c|}
\hline \multirow{2}{*}{$\begin{array}{l}\text { 報告者 } \\
\text { (報告年) }\end{array}$} & \multirow{2}{*}{$\begin{array}{c}\text { 症 例 } \\
\text { (数) }\end{array}$} & \multirow{2}{*}{$\begin{array}{l}\text { 観察 } \\
\text { (年) }\end{array}$} & \multicolumn{3}{|c|}{ 脳梗塞発症率 (\%/yr) } & \multicolumn{3}{|c|}{ 脳仙侐発証率 $(\% / y r)$} \\
\hline & & & プラセボ & 抗血小板薬 & ワルファリン & プラセボ & 抗血小板薬 & ワルファリン \\
\hline $\begin{array}{c}\text { AFASAK }^{1)} \\
(1989)\end{array}$ & $\begin{array}{c}\text { 慢性 NVAF } \\
(1,007)\end{array}$ & 2 & 5.5 & $\begin{array}{c}5.5 \\
(\mathrm{As} 75 \mathrm{mg} / \mathrm{d})\end{array}$ & $\begin{array}{c}2.0 \\
(\text { INR2.8-4.2) }\end{array}$ & 0 & 0 & 0 \\
\hline $\begin{array}{c}\left.\text { BAAT AF }^{2}\right) \\
(1990)\end{array}$ & $\begin{array}{c}\text { NVAF } \\
(420)\end{array}$ & 2.2 & $3.0^{\dagger}$ & & $\begin{array}{l}0.4 \\
(\text { INR } 1.5-2.7)\end{array}$ & 0 & & 0.2 \\
\hline \multirow[t]{2}{*}{$\begin{array}{l}\text { SPAF-I } \\
(1991)\end{array}$} & $\begin{array}{c}\text { NVAF } \\
(421)\end{array}$ & 1.3 & 7.4 & & $\begin{array}{l}2.3 \\
(\text { INR } 2.0-4.5)\end{array}$ & 0.8 & & 0.8 \\
\hline & $\begin{array}{l}\text { NVAF } \\
(1,120)\end{array}$ & 1.3 & 6.3 & $\begin{array}{c}3.6 \\
(\mathrm{As} 325 \mathrm{mg} / \mathrm{d})\end{array}$ & & 0.3 & 0.3 & \\
\hline $\begin{array}{c}\mathrm{CAFA}^{4)} \\
(1991)\end{array}$ & $\begin{array}{c}\text { NVAF } \\
(378)\end{array}$ & 1.3 & 5.2 & & $\begin{array}{c}3.5 \\
(\text { INR2-3) }\end{array}$ & 0 & & 0.5 \\
\hline $\begin{array}{l}\text { SPINAF5) } \\
(1992)\end{array}$ & $\begin{array}{c}\text { 慢性 NVAF } \\
\text { (525) }\end{array}$ & $1.7 \& 1.8$ & 4.3 & & $\begin{array}{c}0.9 \\
(\text { INR } 1.4-2.8)\end{array}$ & 0 & & 0.2 \\
\hline \multirow[t]{2}{*}{${ }_{(1994)}^{\text {SPAF- }{ }^{12)}}$} & $\begin{array}{c}\mathrm{NVAF} \leqq 75 \\
(715)\end{array}$ & 3.1 & & $\begin{array}{c}2.9^{\ddagger} \& 0.5^{\S} \\
(\mathrm{As} 325 \mathrm{mg} / \mathrm{d})\end{array}$ & $\begin{array}{c}1.5^{\ddagger} \& 1.0^{\S} \\
\text { (INR2.0-4.5) }\end{array}$ & & 0.2 & 0.5 \\
\hline & $\begin{array}{c}\mathrm{NVAF}>75 \\
(385)\end{array}$ & 2 & & $\begin{array}{c}7.2^{\ddagger} \& 1.8^{8} \\
(\mathrm{As} 325 \mathrm{mg} / \mathrm{d})\end{array}$ & $\begin{array}{c}4.2^{\ddagger} \& 2.5^{\S} \\
(\text { INR2.0-4.5) }\end{array}$ & & 0.8 & 1.8 \\
\hline \multirow[t]{2}{*}{$\begin{array}{c}\text { AF ASAK- } \Pi^{13)} \\
(1998)\end{array}$} & $\begin{array}{c}\text { 慢性 NVAF } \\
(677)\end{array}$ & 3.5 & & $\begin{array}{c}2.7 \\
(\mathrm{As} 300 \mathrm{mg} / \mathrm{d})\end{array}$ & $\begin{array}{c}3.4 \\
(\text { INR2--3) } \\
3.9 \\
(1.25 \mathrm{mg} / \mathrm{d})\end{array}$ & & & \\
\hline & & & & \multicolumn{2}{|c|}{$\begin{array}{c}3.2 \\
(\text { As } 300 \mathrm{mg} / \mathrm{d}+\mathrm{Wa1} .25 \mathrm{mg} / \mathrm{d})\end{array}$} & & & \\
\hline
\end{tabular}

NVAF : 非弁膜症性心房練動 As：アスピリン Wa：ワルファリン ※：AFASAK は TIA と全身塞栓症, SPAFI, CAFA, SPAF-II は全身塞栓症, AFASAK-II は脳出血を含む $\dagger: 46 \%$ はアスピリンを内服中 $末$ : 梗塞発症り スクあり ミ：梗塞発症リスクなし

表 4 心房細動例を対象とした脳梗塞発症一次子防の成績（本邦）

\begin{tabular}{|c|c|c|c|c|c|c|c|c|}
\hline \multirow{2}{*}{$\begin{array}{l}\text { 報告者 } \\
\text { (報告年) }\end{array}$} & \multirow{2}{*}{$\begin{array}{l}\text { 症 例 } \\
\text { (数) }\end{array}$} & \multirow{2}{*}{$\begin{array}{l}\text { 観察 } \\
\text { (年) }\end{array}$} & \multicolumn{3}{|c|}{ 脳梗塞発症率 $*(\% / \mathrm{yr})$} & \multicolumn{3}{|c|}{ 脳出血発症率 (\%/yr) } \\
\hline & & & 無治療 & 抗血小板薬 & ワルファリン & 無治療 & 抗血小板薬 & ワルファリン \\
\hline $\begin{array}{l}\text { 福並 }^{6)} \\
(1994)\end{array}$ & $\begin{array}{c}\text { 慢性 AF } \\
\text { (113) }\end{array}$ & 3.5 & 6.4 & 4.9 & 2.5 & & & \\
\hline $\begin{array}{c}\text { COOPAT }^{7)} \\
(1996)\end{array}$ & $\begin{array}{c}\text { NVAF } \\
(722)\end{array}$ & 1 & 4.5 & 4.4 & 1.5 & 0.5 & 0.3 & 1.5 \\
\hline $\begin{array}{c}\text { 中島ら畐 } \\
(1997)\end{array}$ & $\begin{array}{c}\text { 慢性 NVAF } \\
\text { (407) }\end{array}$ & $4.3 \& 2.0$ & 6.1 & & 2.2 & 0.1 & & 0.7 \\
\hline $\begin{array}{c}\text { 不整脈䓠物 } 9) \\
\text { 療法研究会 } \\
(1998)\end{array}$ & $\begin{array}{c}\mathrm{AF}(\mathrm{MS} 13 \%) \\
(1,819)\end{array}$ & 4.6 & 2.2 & $\begin{array}{l}1.4(\mathrm{As}) \\
1.1(\mathrm{Ti})\end{array}$ & 1.4 & & & \\
\hline $\begin{array}{c}\text { Tomita 5 }{ }^{10)} \\
(2000)\end{array}$ & $\begin{array}{l}\text { NVAF } \\
(1,650)\end{array}$ & 1.7 & 3.2 & $\begin{array}{l}3.7(\mathrm{As}) \\
3.8(\mathrm{Ti})\end{array}$ & 1.9 & & & \\
\hline $\begin{array}{l}\text { 中島ら } \\
(2001)\end{array}$ & $\underset{(194)}{\text { NVAF }}$ & 3.4 & & & $\begin{array}{c}0.6 \\
\text { (INR1.5-2.4) }\end{array}$ & & & 0.3 \\
\hline & & 2.8 & & & $\begin{array}{l}3.1 \\
\text { (INR1.0-1.5) }\end{array}$ & & & 0.7 \\
\hline
\end{tabular}

AF：心房細動 NVAF：非弁膜症性心房細動 MS：僧帽弁狭㝛症 As：アスピリン Ti：チクロピジン ※不整脈薬物療法研究会, Tomita らの報告は TIA と全身塞栓症を含む 
不全のいずれかの要因を有する群を脳梗塞発症高りス ク群, 上記要因を有さない 65 歳以上例を発症中間リス ク群, 上記要因を有さない 65 歳未満例を発症低リスク 群と定義し，発症高リスク群に対しては原則としてワ ルファリン療法を, 発症中間リスク群に対してはワル ファリンないしアスピリン療法を, 発症低リスク群に 対してはアスピリン療法を推奖している. さらに, 60 歳未満の基礎心疾患を有さないAFに対してはワル ファリンは不要としている. 本ワルファリン療法の対 象には発症低リスク群に属する患者が 16 例 (8\%)，60 歳未満の基碟心疾患を有さない $\mathrm{AF}$ が 6 例 (3\%) 含ま れていた。しかし，この中には抗不整脈薬の効果のな い繰り返す発作性心房細動例, 経食道心臓エコー検查 にて左房内血栓陽性, 中等度以上のモヤモヤエコーま たは左心耳最大流出速度が $20 \mathrm{~cm} / \mathrm{sec}$ 以下を示した 例などが含まれており，また，当施設の慢性 NVAF 469 例を対象とした脳梗塞発症リスクに関する多変量解析 (投稿中)では基赖心疾患を有さないことが梗塞発症率 を低下させる要因にならないという成績もでており， 60 歳未満の基礎心疾患を有さない $\mathrm{AF}$ 全例にワル ファリン療法を行わないことには反対の立場を取りた w.

以上, 本後乃向き検討では NVAF 例の脳梗塞発症一 次予防のためのワルファリン療法は INR 1.5 2.4 が推 奨されることが判明した。 しかし，いかなる症例に対 してワルファリン療法を行うのかに関しては更なる検 討が必要である. 今後, NVAFを対象としたワルファ リンの脳梗塞一次予防効果をみる無作為前向き研究 （当施設も参加している SAKSES）や抗血小板薬の效 果をみる無作為前向き研究 (JAST study) の結果が公 表されれば，本邦に抢ける抗血栓療法の方向づけがよ り明確になると思われる.

稿を終えるに当たって貴重な助言を賜った浅間総合病院 循環器科仲元司先生, 西山 修先生に深謝する.

\section{文献}

1) Petersen P, Boysen G, Godtfredsen J, et al : Placebo-controlled, randomised trial of warfarin and aspirin for prevention of thromboembolic complications in chronic atrial fibrillation. The $\mathrm{Co}$ penhagen AFASAK Study. Lancet 1: 175-179, 1989

2) The Boston Area Anticoagulation Trial for Atrial Fibrillation Investigators: The effect of low-dose warfarin on the risk of stroke in patients with nonrheumatic atrial fibrillation. $\mathrm{N}$ Engl J Med 323: 1505-1511, 1990

3) Stroke Prevention in Atrial Fibrillation Investigators: Stroke prevention in atrial fibrillation study. Final results. Circulation 84 : 527-539, 1991

4) Connolly SJ, Laupacis A, Gent M, et al : Canadian atrial fibrillation anticoagulation (CAFA) study. J Am Coll Cardiol 18:349-355, 1991

5) Ezekowitz MD, Bridgers SL, James KE, et al : Warfarin in the prevention of stroke associated with nonrheumatic atrial fibrillation. $\mathrm{N}$ Engl J Med 327:1406-1412, 1992

6) 福並正剛：慢性心房細動の血栓塞栓症. 心電困 $14: 78-83,1994$

7) 是恒之宏：COOPAT (Cooperative Osaka Platelet Antiaggregation Trial) Study. Therp Res 17: 4429-4433, 1996

8）中島一夫，林由紀子：慢性非弁膜症性心房細動例 の脎血管障害発症率. 一抗血小板療法及び抗凝固 療法の効果一. 脳卒中 $19: 355-360,1997$

9）不整脈薬物療法研究会：心房細動と血栓塞栓症： 多施設共同調查. J Cardiol 31: 227-238, 1998

10) Tomita F. Kohya T. Sakurai M, et al : Prevalence and clinical characteristics of patients with atrial fibrillation. - Analysis of 20,000 cases in Japan-. Jpn Circ J 64 : 653-658, 2000

11) Yamaguchi $T$ for Japanese Nonvalvular Atrial Fibrillation-Embolism Secondary Prevention Cooperative Study Group : Optimal intensity of warfarin therapy for secondary prevention of stroke in patients with nonvalvular atrial fibrillation. A multicenter, prospective, randomized trial. Stroke $31: 817-821,2000$

12) Stroke Prevention in Atrial Fibrillation Investigators: Warfarin versus aspirin for prevention of thromboembolism in atrial fibrillation: Stroke Prevention in Atrial Fibrillation II Study. Lancet $343: 687-691,1994$

13) Gull $\phi \vee$ AL, Koefoed BG, Petersen P. et al : Fixed minidose warfarin and aspirin alone and in combination vs adjusted-dose warfarin for stroke prevention in atrial fibrillation. Second Copenhagen Atrial Fibrillation, Aspirin, and Anticoagulation Study. Arch Intern Med 158 : 1513—1521, 1998

14) Stroke Prevention in Atrial Fibrillation Investigators : Adjusted-dose warfarin versus low-intensity, fixed-dose warfarin plus aspirin for highrisk patients with atrial fibrillation: Stroke Prevention in Atrial Fibrillation III randomised clinical trial. Lancet $348: 633-638,1996$

15）中島一夫，一之瀬正彦：老年者発作性心房細動患 
者の虚血性脳血管障害発祉率に関玄る研究，日老

医誌 $33: 273--277,1996$

16) Hart RG. Sherman DG. Easton JD, et al : Preven- tion of stroke in patients with nonvalvular atrial fibrillation. Neurology $51: 674-681,1998$

\title{
Abstract \\ Anticoagulation with warfarin for primary prevention of ischemic stroke in patients with nonvalvular atrial fibrillation
}

\author{
Kazuo Nakajima, M.D., Yukiko Hayashi, M.D. \\ Department of Internal Medicine. Asama General Hospital
}

We conducted a retrospective analysis of anticoagulation with warfarin for the primary prevention of ischemic stroke in patients with nonvalvular atrial fibrillation. The study population comprised 194 patients with a mean age of 65.1 years at the onset of atrial fibrillation, and 69.5 years at the start of warfarin therapy, including 124 men and 70 women. Of the participants, $81 \%$ had chronic atrial fibrillation. During a mean follow -up period of 3.1 years, 11 ischemic strokes (incidence, $1.8 \%$ per year) and 3 brain hemorrhages (incidence, $0.5 \%$ per year) occurred. According to the mean INR, the patients were divided into 2 groups: 92 patients with low dose warfarin (INR, 1.5 to 2.4) and 102 patients with super low dose warfarin (INR, 1.0 to 1.5). The incidence of ischemic stroke was significantly lower in the low dose warfarin group than in the super low dose warfarin group $(0.6$ versus $3.1 \%$ per year, $\mathrm{p}=0.028)$. The rates of brain hemorrhage gave rise to no difference between the 2 groups $(0.3$ versus $0.7 \%$ per year, $p=0.522)$. The present analysis suggests a preference for low dose anticoagulation with warfarin in the primary prevention of stroke among cases of nonvalvular atrial fibrillation in Japan. However, further prospective studies are needed to establish the optimal dose of warfarin.

(Jpn J Stroke 23: 188-194, 2001) 